7. Ершов П. М.Общение на уроке, или Режиссураповедения учителя/ Ершов П.М., Ершова А.П., Букатов В.М.; 2-е изд., перераб. и дополн. - М., 1998. - 336 с.

8. Загвязинский В.И. Развитие педагогического творчества учителей / В.И. Загвязинський. - М.: Знание, 1986. - 40 с.

9. Кан-Калик, В.А. Педагогическая деятельность как творческий процесс / В.А. Канн-Калик. -Грозный, 1976. - 286 с.

10. Лабунская В.А. Невербальное поведение (социально-перцептивный подход) / В.А. Лабунская. - Ростов-на-Дону: РГУ, 1986. -136с.

11. Макаренко А.С. Педагогическая поэма/ А.С.Макаренко/ сост., вступ. ст., примеч., пояснения С.Невская - М.: ИТРК, 2003. - 736 с.

12. Раппопорт С.Х. Эстетика общения/ С.Х.Раппорт. // Эстетическая культура и эстетическое воспитание. -М.: Музыка, 1983. - 303с.

13. Рыданова И. И. Основы педагогики общения/ И.И.Ріданова. - Минск, 1998. - 320 с.

14. Словарь современного русского литературного языка: В 20 т. - М., 1991. - Т. 1.- 863 с.

15. Станиславский К.С. Работа актера над собой/ К.С.Станиславский // Собр. соч.: В 8 т. - T. 3. -567 c.

16. Сухомлинський А. В. Идти вперед! / В.А. Сухомлинский// Нар. образование, 1989. - №8. - С.70-78.

17. Фасцинація : http://ru.wikipedia.org

18. Филонов, Л.Б., Психолого-педагогическая антропология Текст. : [курс лекций и тестовые задания] / Н.А. Ананьева, Л.Б. Филонов. М. : МГОУ, 2007. - 152 с.

19. Шіллер Ф. Естетика/ Ф.Шіллер. - К., Мистецтво, 1974. - 360 с.

Стаття надійшла до редакції 01.06.2012 р.

\title{
ДІАЛОГІЧНА КУЛЬТУРА ЯК СКЛАДНИК ПЕДАГОГІЧНОЇ КОМПЕТЕНТНОСТІ МАЙБУТНІХ УЧИТЕЛІВ ПОЧАТКОВОї ШКОЛИ
}

Довбенко С. Ю. Діалогічна культура як складник педагогічної компетентності майбутніх вчителів початкової школи.

У статті розглянуто проблему формування діалогічної культури як складника педагогічної компетентності майбутніх вчителів початкової школи. Педагогічна компетентність має забезпечувати належну професійну підготовку випускника в умовах ступеневої освіти та його конкурентну здатність на ринку освітніх послуг.

Ключові слова: діалогічна культура, професійна компетентність.

Довбенко С.Ю. Диалогическая культура как составляющая педагогической компетентности будущих учителей начальной школы.

В статье рассмотрены проблемы формирования диалогической культуры как составной педагогической компетентности будущии учителей начальной иколь. Педагогическая компетентность должна обеспечивать надлежамую профессиональную подготовку выпускника в условиях высшей школы его конкурентную способность на рынке образовательных услуг.

Ключевые слова: диалогическая культура, профессиональная компетентность.

Dovbenko S. Dialogic culture as a component of the teaching competence of future teachers in primary schools.

In article problems of formation of dialogical culture as compound pedagogical competence of future teachers of elementary school are considered. Pedagogical competence should provide appropriate vocational training of the graduate in the conditions of the higher school his competitive capacity in the market of educational services.

Key words: dialogical culture, professional competence. 
Постановка проблеми. Реформування сучасної системи навчання, перехід на комптентнісний підхід диктується вимогами економіки та новим розумінням ролі людського чинника в соціальному житті, перетворенні суспільства на демократичних і гуманістичних засадах. Результативність цього процесу неможлива без грунтовного аналізу рівня професіоналізму вчительських кадрів і пошуку шляхів подальшого удосконалення якості їхньої підготовки. Діалогічне навчання висуває особливі вимоги як до особистості вчителя, так і до набору його умінь і навичок, що визначають результативність учительської праці. Без певного рівня розвитку готовності до діалогічного навчання не можна досягти якісної зміни в професійній готовності майбутнього вчителя, забезпечити творче виконання ним своїх професійних функцій. Саме компетентнісний підхід розглядається як один із важливих концептуальних принципів, який визначає сучасну методологію оновлення змісту освіти.

Останні публікації. Використання різноманітних методів (гри, діалогу, дискусії, рольовій ситуації) забезпечує перевагу смислової пам'яті над механічною, стійкість уваги й активної розумової діяльності, оригінальність уяви (М. Каспарова, Н. Баришнікова); забезпечує студентам можливість оцінити власні погляди, переконання і позицію на проблему, що розглядається, установки і стереотип поводження, за їх допомогою озброює майбутніх педагогів комунікативною стратегією і культурою діалогічного спілкування (Г. Грищенкова); залучення студентів до мовленнєво-ігрової діяльності створює умови для вироблення і закріплення в них стратегії i тактики професійного спілкування.

Мета статі. Розглянути проблему формування діалогічної культури як складника педагогічної компетентності майбутніх вчителів початкової школи. Педагогічна компетентність має забезпечувати належну професійну підготовку випускника в умовах ступеневої освіти та його конкурентну здатність на ринку освітніх послуг.

Отримані результати. Під компетенціями ми розуміємо сукупність взаємозалежних якостей особистості (знання, уміння, навички, способи діяльності), необхідних для якісної продуктивної діяльності. Компетентність визначаємо як володіння відповідними компетенціями. Аналіз визначень педагогічної компетентності дає змогу стверджувати, що педагогічна компетентність є системою наукових знань, інтелектуальних і практичних умінь i навичок, особистісних якостей i утворень, яка при достатній мотивації та високому рівні професійності психічних процесів забезпечує самореалізацію, самозбереження та самовдосконалення особистості педагога в процесі професійної діяльності [6].

Бесіди, інтерв'ю, анкетування, систематичне спостереження дозволили виявити причини недооцінки і неоптимального використання діалогу в навчальному процесі. $75 \%$ опитаних учителів мотивували низький інтерес до навчального діалогу переповненістю класів (понад 40 учнів); 57\% учителів виокремили з-поміж причин недостатній рівень комунікативної культури, 
що значно ускладнює спілкування з учнями в ході уроку. 68\% опитаних учителів 3-поміж причин неефективного використання навчального діалогу назвали власну непідготовленість до діалогічного навчання.

Ось типові відповіді на запитання пропонованої анкети: «В інституті нас не вчили культурі спілкування в навчальній роботі, прийомам педагогічної взаємодії і співпраці з учнями. На уроці мені легше самій все пояснити, ніж розворушити клас на бесіду»; «Найменше ми підготовлені до спілкування 3 дітьми. Важко починати роботу, коли не знаєш, як підступитися до них, як установити з ними контакт. Без цих знань і умінь не тільки діалог, але і проста бесіда не буде ефективною» тощо.

Аналіз отриманих фактів дозволяє говорити про неефективність педагогічної підготовки майбутніх педагогів в умовах вищої школи. Викладання педагогічних дисциплін будується переважно на монолозі, діалогічний підхід до організації навчальних занять у вищій школі не одержав належної уваги. Навчальний діалог не використовується як ефективний засіб активізації пізнавальної діяльності студентів, формування самостійності їхніх поглядів і суджень. Організація педагогічної практики не націлена на реалізацію діалогічного навчання в навчальному процесі загальноосвітньої школи. Виходячи на педагогічну практику, студенти четвертих і п’ятих курсів не мають цілісного уявлення про навчальний діалог як засіб особистісно орієнтованого навчання учнів, не володіють ні методикою, ні технологією діалогічного навчання [2].

Результативності у формуванні культури діалогічного навчання можна досягти, якщо забезпечити кожному студенту свободу вибору дій і ситуацію успіху, поставити його в ситуацію активного суб'єкта навчання, щоб створити умови, які дозволили б майбутнім педагогам самостійно здійснювали пізнавальні відкриття, відчувати потребу в спільному пошуку істини і вирішенні навчальної проблеми засобами діалогу.

Аналіз наукової літератури дозволив надати уточнене визначення «діалогічна культура», так 3 педагогічної позиції у процесі навчання культура спілкування визначається як особистісна якість та здатність індивіда здійснювати комунікацію, адекватну певному типу ситуацій.

Для визначення рівня діалогічної культури у майбутніх педагогів використовувалися цілеспрямовано створені комунікативні ситуації-діалоги. У таких ситуаціях-діалогах студенти не просто слухають, сприймають i запам'ятовують навчальну інформацію, а взаємодіють із викладачем i однокурсниками, співпрацюють через діалогічне спілкування в заданій ситуації, висловлюють своє ставлення до діалогу, виявляють особистісні якості і використовують діалогічні уміння, діючи в комунікативній ситуації. У таких ситуаціях виявляється діалогічний підхід до особистості задля визначення рівня їі комунікативної культури.

Оскільки свідомість студентів має діалогову природу, найбільш адекватним методом вивчення первісного стану досліджуваного явища $\epsilon$ ситуації довірливого обговорення, у яких гарантовано рівноправну позицію 
учасників і відсутність «тиску» із боку викладача. Під час перебігу створених ситуацій діалогового спілкування студенти висловлюють свій погляд, знання набувають особистісного сенсу, створюється атмосфера зацікавленості. Інтерес розковує студентів, їхнє мовлення, стимулює свободу дій. Усе це дозволяє одержати цілісну картину досліджуваного явища. Пошук виходу 3 діалогічних ситуацій, які моделюються на навчальних заняттях, пропонує послідовність дій студентів:

- привнесення власних міркувань і емоційно-ціннісного ставлення до досліджуваного матеріалу;

- структурування навчальної інформації у формі образу-питання, образу-варіанту;

- колективний пошук розв'язання проблеми;

- спілкування у формі діалогу для оптимального виходу 3 запропонованої ситуації.

У процесі модельованої у такий спосіб професійної діяльності здійснюється регулювання характеру мотивації до діалогічного спілкування, переживання почуття задоволення від власних зусиль і зайнятої позиції в діалозі, створюється ситуація успіху, що $\epsilon$ основою для формування професійної компетентності майбутніх педагогів до діалогічного навчання.

Висновки. Комунікативна компетенція - це вміння педагога будувати ефективні комунікативні дії в певному колі ситуацій міжособистісної взаємодії, це знання фахівцем закономірностей різних форм спілкування $\mathrm{i}$ правил поведінки в різних ситуаціях, уміння сформувати тактичний план i реалізувати його на основі соціальних навичок.

У дослідженні встановлено, що одним з важливих шляхів формування діалогічної культури $є$ впровадження в педагогічну підготовку ситуацій діалогічного спілкування, завдань творчого плану, рольових ігор, педагогічних задач, системи вправ на відпрацьовування і закріплення діалогічних умінь, моделювання уроків-діалогів, мозкового штурму, різних тренінгів діалогічного спілкування. Подальшу свою роботу ми вбачаємо у розробленні діалогічних завдань, які сприяють формуванню діалогічної культури майбутніх учителів початкової школи.

\section{Література}

1. Кондрашова Л.В. Имитационно-игровое обучение в высшей школе / Л.В. Кондрашова, М.Г. Виевская, Л.А. Савченко - Кр. Рог, 2001. - 167 с.

2. Морозов В.В. Можливості ігрового навчання як процесу підвищення діалогічного наспіл кування майбутніх педагогів: [зб. наук. пр.] / В.В. Морозов, Л.О. Савченко. -Кривий Ріг: КДПУ. - 2005. - 156 с.

3. Мухина Т.К. Диалог как форма оптимизации педагогического процесса / Т.К. Мухина // Сов. педагогика. - 1989. - №10. - С. 74-78.

4. Палюк Л.Г. Проблема обучения устному деловому общению будущих специалистов банковской сферы / Л.Г. Палюк // Іноземні мови. - 1999. - №3. - С. 41-44.

5. Професійне становлення майбутнього вчителя: монографічний огляд / за редакцією д.пед.н., професора Л.В.Кондрашової. -Кривий Ріг, 2006. - 327 с.

6. http://www.kgpa.km.ua/

Стаття надійшла до редакції 30.05.2012 p. 